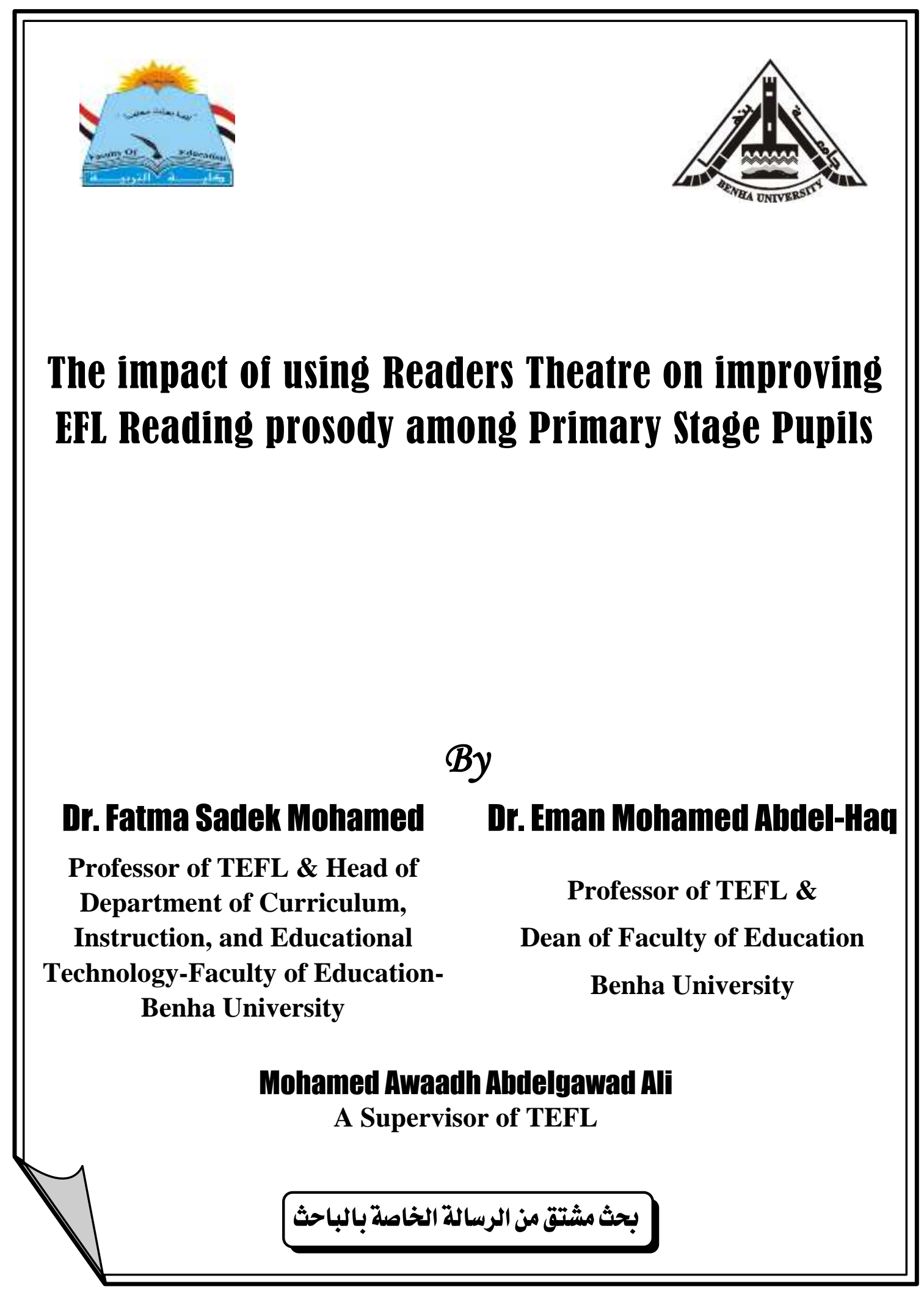




\section{The impact of using Readers Theatre on improving EFL Reading prosody among Primary Stage Pupils}

\section{By}

\section{Dr. Fatma Sadek Mohamed}

'rofessor of TEFL \& Head of Department

of Curriculum, Instruction, and

Educational Technology-Faculty of

Education-Benha University

\section{Dr. Eman Mohamed Abdel-Hau}

Professor of TEFL \&

Dean of Faculty of Education Benha University

\section{Mohamed Awaadh Ahdelgawad Ali}

A Supervisor of TEFL

\section{Ahstract}

The purpose of the present study was to investigate the impact of using Readers Theatre on improving EFL Reading prosody among Primary Stage Pupils. The design of the study was one group design; the participants of the study were from 6th year Primary Stage pupils. $(\mathrm{N}=30)$, the pupils were instructed by using Readers Theatre. The instruments of the study were two instruments: A pre - post oral reading prosody test, and a Multidimensional Fluency Scale for correcting the test. The test was administered to the participants before introducing Readers Theatre. Following to applying Readers Theatre, the test was introduced to the participants. The researcher prepared a program Based on Readers Theatre to improve EFL Reading prosody of the participants. Findings of the study showed that EFL Reading prosody skills of the participants improved due to the effect of using Readers Theatre. This proved that Readers Theatre is effective in developing EFL Reading prosody skills among 6th year Primary Stage pupils.

Keywords: EFL Reading prosody skills - Readers Theatre. 


\section{استخدام هسرح القراء لتحسين القراءة التعبيرية باللغة الإنجليرية لد الدى تلاهيذ المرحلة الابتدائية}

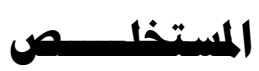

تهدف الدراسة الحالية إلى تقصي أثر استخام مسرح القراء على تحسين القراءة

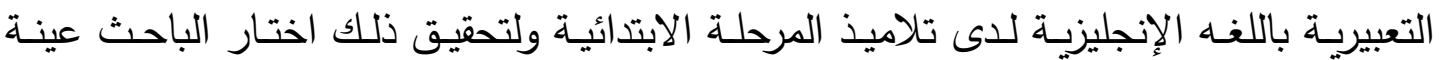

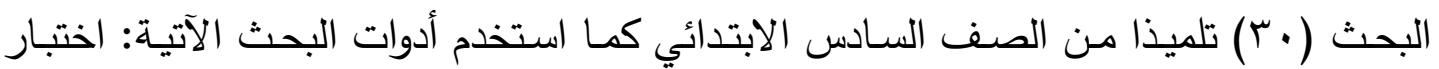

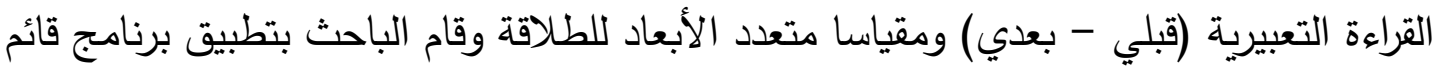

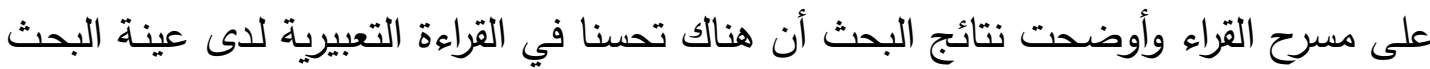
نتيجة لاستخدام مسرح القراء.

الكلمسـاتالمقتــاحيـة: القراءة التعبيرية باللغة الإنجليزية - مسرح القراء. 


\section{Introduction}

English language is the learner's means to express his/her own ideas, emotions, and exchange information with others. This happens through different circumstances; in order to be able to use, communicate, and incorporate, through variety of linguistic and real life situations. It is reasonable that the process of teaching English language needs to be developed nowadays.

Selim (2004) investigated the third year prep pupils inability to read the reading texts of the English textbook Hello 5 in the light of some reader-related factors and some text-related factors using several readability tools. Reading instruction depends on a teacher's knowledge and effective use of instructional methods (Commeyras et al., 2007: 267-270). English has been a required foreign language for all children. However, after years of English as a foreign language (EFL) instruction, most children still cannot read, write, or communicate in English (Tsou, 2011: 727- 728).

Reading fluency is defined as the number of correctly read words per minute when orally reading connected text. ORF is often a target area for intervention and assessment when word recognition, slow or choppy oral reading, and comprehension deficits are observed (Glazer, 2007: 4). Kariuki (2012: 2) indicated that students taught using readers' theatre-based teaching scored significantly higher than students taught using traditional-based instruction. Fry (2010: 4) investigated whether the theory of automaticity impacted the intentional use of repeated reading within Readers Theater.

\section{Theoretical Background \& Review of Literature:}

Reading fluency refers to reading text quickly, accurately, with good prosody, and with comprehension (Hussien, 2014: 75). Fluent readers decode words accurately and automatically, without use of their limited attention or conscious cognitive resources. (Rasinski, 2004: 5). 
Jeon (2012: iii) clarified that paired repeated reading improved L2 readers' oral reading fluency. El-Garawany (2010) investigated the effects of repeated reading strategies on developing oral reading fluency, with its three components: accuracy, rate and prosody among EFL prospective teachers. Ahmed (2013) investigated the effect of using the task-based approach on developing the oral fluency of the first secondary graders.

The demands for fluent, active and interactive graduates were increasingly stressed in all stages. Teachers must apply instructional strategies that help readers transition from simple decoding of words to fluent word identification (Mraz et al., 2013). Farahat (2014) investigated the effectiveness of using peer-assisted reading strategies in developing sixth graders' reading fluency in English as a foreign language. Hegazy (2012) conducted a study to develop the necessary oral reading fluency (rate, accuracy and prosody) skills for Egyptian EFL second year preparatory school students. Za'za' (2014: 1-6) examined the effect of teacher- and student-mediated repeated reading on the oral reading fluency among sixth- grade primary stage pupils. Diab (2015: IV) presented a suggested program for developing students' EFL reading fluency skills.

Marc (1994) discussed prosody as a marker of information flow in spoken discourse. The analysis of spontaneous discourse prosody both from the speaker's and the listener's point of view, showed the following specific results. With regard to the speaker, it was found that larger-scale information units are indeed phonetically encoded in pausal and melodic properties. A speaker may separate two successive units by the use of a long pause. At any rate, it can be concluded that speakers use local prosodic devices to signal the boundaries of a discourse unit. Two prosodic variables were investigated: speech melody and pauses. Melodically, it was found that local intonation features (falling \s. rising tones) are employed to indicate discourse boundaries. 
Readers Theatre is an ideal for applying a Vygotskian teaching approach; it requires that students interact with one another. Through the process of preparing readers' theater performance, students constructively criticize one another; the teacher provides the necessary support and modeling as well (Caudill-Hansen, 2009: 24). The child's mind contains all stages of future intellectual development; they exist in complete form, in anticipation of the proper moment to appear. Signs and words serve children as a means of social contact with other people (Vygotsky, 1930: 3- 14), and (Vygotsky, 1978: 26 - 57).

Trainin and Andrzejczak (2006: 1-8) analyzed the impact of Readers Theatre in improving oral reading fluency. Callard (2008: 2) tried to determine if Reader's Theater would increase reading fluency, and motivation in at-risk third grade students. Morales (2013) referred that Reader's Theater was implemented for the students to determine how Reader's Theater would affect English Language Learners' (ELL) reading fluency, and attitude. Gummere (2004: 1) supported using Readers Theater to increase oral reading fluency, and particular aspects of motivation with first graders. (Sailer, 2006: 5) assured that one way to improve fluency, readers' confidence, and motivation, was through reader's theater. Moran (2006: 317) mentioned that Readers Theater was beneficial for children who could read independently. * Helwa (2014: 291) investigated the effects of using reader's theatre based instruction on improving EFL oral reading fluency, among preparatory stage pupils.

\section{Context of the Problem:}

Consistent with the researcher's experience, as an EFL supervisor, EFL reading prosody skills are not taught in schools, i. e. they are neglected. The related studies supported this point of view such as: Alhaidari (2006), Alqayedy (2014), Al-Sanhani (2015), Diab (2015), El-Garawany (2010), ElGarhy (2017), Farahat (2014), Hegazy, (2012), Hussien (2014), Ramadan 
(2016), and Za'za' (2014). A pilot study was conducted to participants of $(\mathrm{N}=30)$ from the primary stage; sixth year in El-Sharqia governorate, Minia ELQamh Educational Directorate, Kafr Shaaban primary school. Findings exposed that there was weakness concerning EFL reading prosody skills among EFL sixth year primary school pupils.

\section{Statement of the problem:}

Despite the importance of EFL reading prosody for the primary stage, and the vital need to build up them, there is a lack in EFL reading prosody skills for the pupils of this stage. The problem of the present study is the weakness of EFL reading prosody among sixth year primary school pupils.

\section{Questions of the study:}

To work out the problem, the following questions are suggested:

1- What are the EFL reading prosody skills necessary for sixth grade primary stage pupils?

2- What are the features of a program- Based on Readers Theatre, suitable for developing EFL reading prosody skills among sixth grade primary stage pupils?

3- What is the effect of a program- Based on Readers Theatre on developing EFL reading prosody skills among sixth grade primary stage pupils?

\section{Hypotheses of the study:}

1- There is a statistically significant difference between the mean scores of the participants in the pre/post assessment of EFL oral reading prosody, in favour of, the post assessment.

2- There is a statistically significant difference between the mean scores of the participants in the pre/post assessment of overall oral reading fluency, in favour of, the post assessment. 


\section{Delimitations of the study:}

The present study is delimited to:

a) Participants from sixth year primary school pupils.

b) The prescribed text book of sixth year primary stage, and selected scripts, that support the same topics at the stated curriculum.

c) Some EFL reading prosody skills required for sixth year primary school pupils.

\section{Instruments of the study:}

The present study consisted of two instruments as follows:

a) A pre - post oral reading prosody test.

b) Multidimensional Fluency Scale for correcting the test.

\section{Participants of the study:}

Participants of the study were (N.30) pupils, one group design, from the primary stage; sixth year at the second semester 2018-2019, in El-Sharqia governorate, Minia ELQamh Educational Directorate, Kafr Shaaban primary school, taught by the new treatment; a program Based on Readers Theatre for developing EFL reading prosody.

\section{Procedures of the study:}

To implement the present research, the following procedures will be followed:

\section{Identifying the EFL reading prosody skills necessary for sixth grade primary stage pupils through:}

a) Reviewing literature and previous studies related to in EFL reading prosody skills.

b) Preparing a list of EFL reading prosody skills necessary for sixth grade primary stage pupils. 
c) Submitting the EFL reading prosody skills list to jury members to verify its validity.

d) Modifying the list according to the jury members' opinions.

Identifying the features of a program Based on Readers Theatre, suitable for developing EFL reading prosody skills among sixth grade primary stage pupils through:

a) Reviewing literature and previous studies related to Readers Theatre.

b) Identifying the components of a program Based on Readers Theatre; the aims, content, methods of teaching, and evaluation types.

c) Selecting techniques, tasks, activities, included in a program Based on Readers Theatre.

d) Preparing the program Based on Readers Theatre; to develop EFL reading prosody skills among sixth grade primary stage pupils.

Identifying the effect of a program Based on Readers Theatre on developing EFL reading prosody skills among sixth grade primary stage pupils through:

a) Preparing a pre- post EFL reading prosody skills test, and using Multidimensional Fluency Scale for correcting the test.

b) Submitting the pre- post EFL reading prosody skills test, to jury members; to verify its validity.

c) Modifying the test, according to the jury members' opinions.

d) Setting the test in its final version.

e) Selecting participants, one group design, from sixth grade primary stage pupils.

f) Administering the EFL reading prosody skills pre-test, to the study participants, before using the program Based on Readers Theatre; in order to identify their level.

g) Teaching the study participants, using the Program Based on Readers Theatre. 
h) Administering the EFL reading prosody skills post-test, to the participants, after presenting the program Based on Readers Theatre.

\section{After applying the post test, and collecting data, correlation factor is calculated.}

Collecting data of the study and conducting statistical analysis.

Analyzing the collected data quantitatively.

Interpreting the findings of the study.

Presenting recommendations and suggestions.

Multidimensional Fluency Scale:

Table (1): Multidimensional Fluency Scale

Use the following rubric (1-4) to rate reader fluency in the areas of expression and volume, phrasing, smoothness, and pace.

a) Expression and Volume

1- Reads words as if simply to get them out. Little sense of trying to make text sound like natural language. Tends to read in a quiet voice.

2- Begins to use voice to make text sound like natural language in some in areas of the text but not in others. Focus remains largely on pronouncing the words. Still reads in a quiet voice.

3- Makes text sound like natural language throughout the better part of the passage. Occasionally slips into expressionless reading. Voice volume is generally appropriate throughout the text.

4- Reads with good expression and enthusiasm throughout the text. Varies expression and volume to match his or her interpretation of the passage.

b) Phrasing

1- Reads in monotone with little sense of phrase boundaries; frequently reads word-by-word.

2- Frequently reads in two- and three-word phrases, giving the impression of choppy reading; improper stress and intonation fail to mark ends of sentences and clauses.

3- Reads with a mixture of run-ons, mid-sentence pauses for breath, and some choppiness; reasonable stress and intonation.

4- Generally reads with good phrasing, mostly in clause and sentence units, with adequate attention to expression. 
Use the following rubric (1-4) to rate reader fluency in the areas of expression and volume, phrasing, smoothness, and pace.

\section{c) Smoothness}

1- Makes frequent extended pauses, hesitations, false starts, soundouts, repetitions, and/or multiple attempts.

2- Experiences several "rough spots" in text where extended pauses or hesitations are more frequent and disruptive.

3- Occasionally breaks smooth rhythm because of difficulties with specific words and/or structures.

4- Generally reads smoothly with some breaks, but resolves word and structure difficulties quickly, usually through self-correction.

\section{d) Pace}

1 - Reads slowly and with difficulty.

2- Reads moderately slowly.

3- Reads with an uneven mixture of fast and slow pace.

4- Consistently reads at conversational pace; appropriate rate throughout reading.

Scores range 4-16. Generally, scores below 8 indicate that fluency may be a concern. Scores of 8 or above indicate that the students are making good progress in fluency.

Adapted from: Zutell, J., \& Rasinski, T. V. (1991). Training teachers to attend to their students' oral reading fluency. Theory Into Practice, 30, 211-217.

Educational Leadership (2004). What Research Says About Reading.

61, 6: 46-51.

\section{The material of the study:}

The material of present study consists of a program based on Readers' theatre for developing oral reading prosody among the primary stage pupils.

\section{The content of the program:}

The present study program consisted of fifteen sessions as well as an orientation session. These sessions are based on incorporating oral reading instruction via Readers Theatre into the classroom which assists learners to develop their reading prosody. The program sessions were 
composed of two parts: First, student/pupil reads aloud the dialogue script for practising the different components of fluency through narration of the text. The pupils practise turn - taking in the narration process.

Second, pupils read aloud a text. Immediately following oral reading, pupils were given oral activities based on the reading given material. Pupils' reading attempts indicating some difficulty were classified into four categories:

1- Self -correction,

2- repetition,

3- pauses,

4- and partials.

\section{Repeated and paired reading:}

\section{In repeated reading, the teacher follows several steps:}

- First, the teacher selects a text of interest

- It can be of any sort poem, short essay, fiction etc. and he reads with approximately $90 \%$ accuracy on the initial reading.

- Second, the teacher selects a passage of 50 - 300 words, and emphasizes automatic word recognition and the pupils are to move away from word - by - word reading and try to reach their independent level go - 100\% accuracy.

- Third, The pupils begin to view the procedure of repeated reading taking a role zooming through the text in order to reach as high a word per minute rating as possible, refocusing on appropriate pacing and the need to sound expressive. The teacher allows them to listen to themselves read with expressive speed on a tape and demonstrate what they sound like by modeling.

- Fourth, the teacher keeps the pupils from concentrating too heavily on word recognition at the expense of comprehension. 
- Fifth, the teacher asks the pupils to reread the passage in pairs or in groups; to improve their prosody. The first to reader then reads the passage aloud to the partner and assesses his/her own performance, The partner listens carefully to each of the readings and after the second and third attempts, and comments on the ways, the performance has improved. Finally, the final step involves the pair matching roles and completing the procedures with the second reader and the third one.

\section{Findings and discussion:}

\section{Findings of Hypothesis (1):}

The first hypothesis states that "There is a statistically significant difference between the mean scores of the participants in the pre/post assessment of EFL oral reading prosody, in favour of, the post assessment."

The mean scores of the participants in the pre/post assessment of EFL oral reading prosody is calculated, where "t-value" is (9.832) which is significant at the (0.01) level of significance. Thus, the first hypothesis was validated.

The following table shows the mean scores, standard deviation, $t$ value and the level of significance.

Table (2): " $t$ " test between the mean scores of the participants in the pre/post assessment of EFL oral reading prosody.

\begin{tabular}{|c|c|c|c|c|c|c|c||}
\hline Skill & Assessment & N & Mean & S. D. & T & df & Sig. \\
\hline \hline \multirow{2}{*}{$\begin{array}{c}\text { EFL oral reading } \\
\text { prosody }\end{array}$} & Pre & 30 & 5.733 & 1.413 & & & \\
\cline { 2 - 7 } & Post & 30 & 7.733 & 1.461 & 9.832 & 29 & 0.01 \\
\hline
\end{tabular}

Table (2) shows that the mean scores is (5.733) for the pre assessment, and (7.733) for the post assessment and the standard deviation is (1.413) for the pre assessment and (1.461) for the post assessment. 
This advance in EFL oral reading prosody skills is due to the program based on Readers Theatre which was implemented during the treatment.

\section{Findings of Hypothesis (2):}

The second hypothesis states that "There is a statistically significant difference between the mean scores of the participants in the pre/post assessment of overall oral reading fluency, in favour of, the post assessment."

The mean scores of the participants in the pre/post assessment of overall oral reading fluency is calculated, where "t-value" is (4.210) which is significant at the (0.01) level of significance. Thus, the second hypothesis was validated.

The following table shows the mean scores, standard deviation, $\mathrm{t}$ value and the level of significance.

Table (3): " $t$ " test between the mean scores of the participants in the pre/post assessment overall oral reading fluency.

\begin{tabular}{||c|c|c|c|c|c|c|c||}
\hline Skill & Assessment & N & Mean & S. D. & T-Value & df & Sig. \\
\hline \hline $\begin{array}{c}\text { overall oral } \\
\text { reading fluency }\end{array}$ & Pre & 30 & 24.527 & 8.355 & & & \\
\cline { 2 - 6 } & Post & 30 & 45.827 & 14.196 & & 29 & 0.01 \\
\hline
\end{tabular}

Table (3) shows that the mean scores is (24.527) for the pre assessment, and (45.827) for the post assessment and the standard deviation is (8.355) for the pre assessment and (14.196) for the post assessment.

This advance in overall oral reading fluency is due to the program based on Readers Theatre which was implemented during the treatment.

\section{Discussion of the Findings:}

1- Regarding the first hypothesis, findings showed that there is a statistically significant difference between the mean scores of the participants in the pre/post assessment of EFL oral reading prosody, in favour of, the post assessment because "t-value" is (9.832) which is significant at the (0.01) level of significance. Therefore, the first hypothesis was authenticated. 
This progress in EFL oral reading prosody skills is owing to the program based on Readers Theatre which was applied during the treatment.

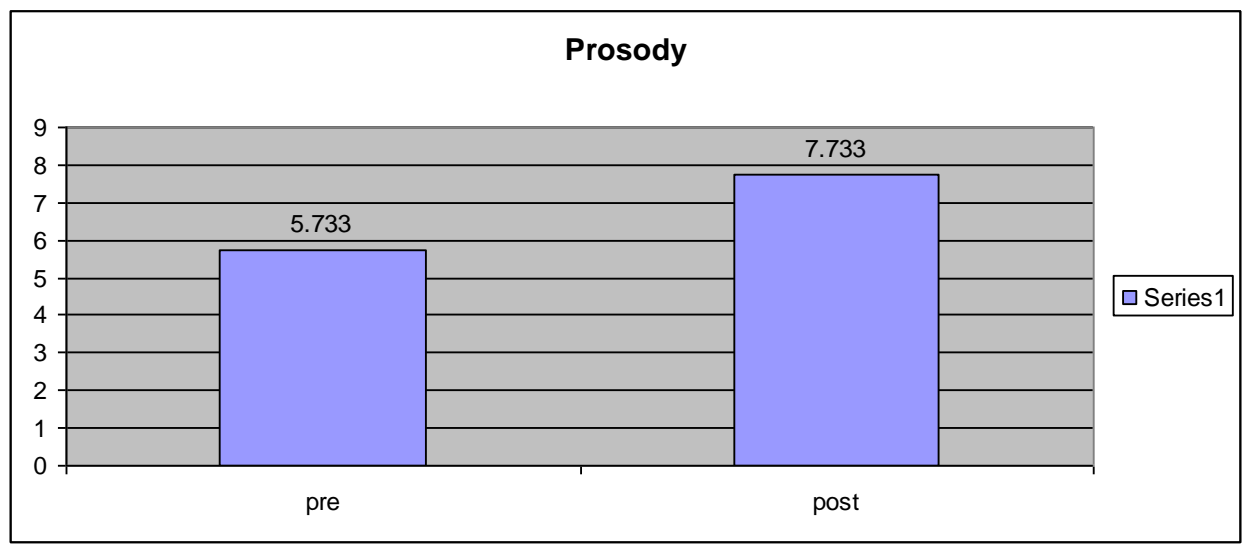

Fig. (1) The mean scores of the participants in the pre/post assessment of EFL oral reading prosody.

2- Regarding the second hypothesis, findings showed that there is a statistically significant difference between the mean scores of the participants in the pre/post assessment of overall oral reading fluency, in favour of, the post assessment because "t-value" is (17.513) which is significant at the (0.01) level of significance.

Therefore, the fourth hypothesis was authenticated.

This progress in overall oral reading fluency is owing to the program based on Readers Theatre which was applied during the treatment.

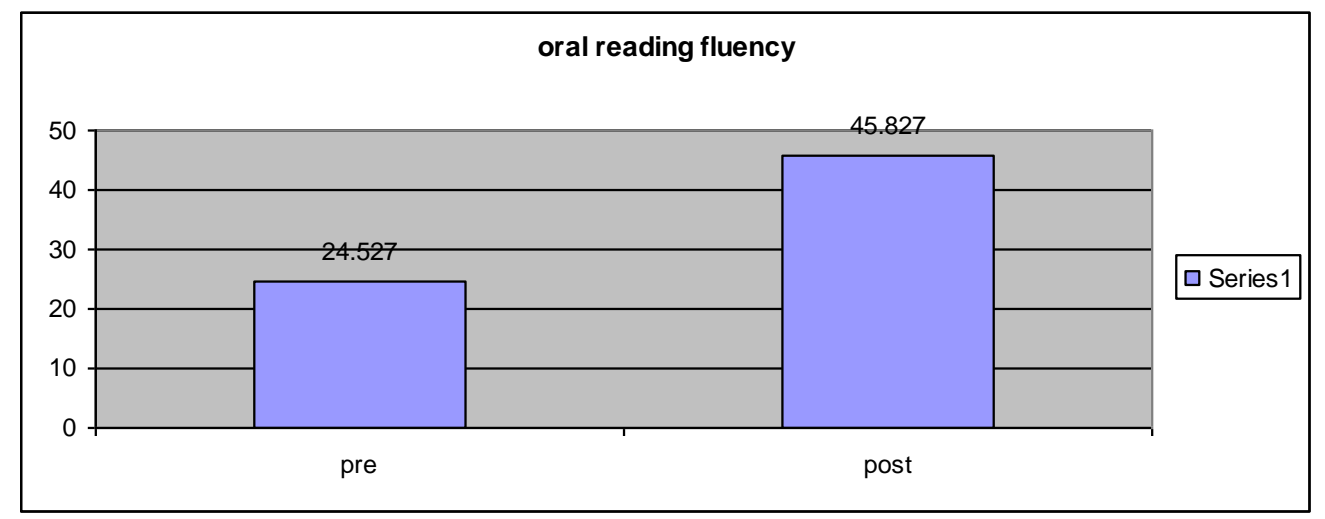


Fig. (2) The mean scores of the participants in the pre/post assessment of overall oral reading fluency.

The findings of the present study indicate that errors' patterns and other features of oral reading prosody of primary stage pupils are very similar, just as in most studies with English speaking children, good readers in the present study made a large proportion of semantically and syntactically acceptable errors whereas poor readers made a significantly large proportion of phonological errors.

This result is consistent with Marc (1994). In the present study, poor readers made many more reading errors and read less fluently and expressively than average, and good readers at the beginning of the program. Although the number of reading errors did not differ significantly among the groups, there was a significant reading ability effect on the reading speed. Poor readers read slowly, but their reading processes were similar to good and average readers. This result is consistent with Jeon (2012), this may be due to the fact that the present study program focused on expressiveness as one clue to the extent to which comprehension is involved during reading.

The present study program aimed to help the pupils pause, repeat or engage in a partial process. This is based on the fact that the more the child is comprehensive, the easier it is for him to follow the sequence of the words, this producing more syntactically and semantically acceptable errors.

The results are consistent with Rasinsky (2004). The results also revealed that repeated reading on the theatre practice were effective for the pupils who are considered to be slow.

The pupils' reading fluency improved in most offered reading texts. This may be due to the fact that Readers Theatre as a way of treatment is reading aloud of writing text to communicate a message in which the pupils are engaged and involved in the case which increased the pupils 
reading self-confidence by practicing multiple reading of a text thereby improving comprehension, fluency and accuracy. The rereading required in Readers Theatre presentation gave pupils valuable practice in moving from decoding printed words into sounds to fluid and automatic word recognition. This result is consistent with (Mraz et al., 2013).

The present study showed that the pupils self-confidence was also increasing along with reading fluency-decoding and comprehension. This can be investigated in a variety of ways. One of these ways is that Readers Theatre offered different texts to read aloud. These texts varied in length to meet all the pupils' levels and depending on the pupils' proficiency level, the case which helped them to go on with various reading texts.

The study findings are consistent with the automaticity theory with the assertion that first account accurate word recognition frees cognitive resource for reading comprehension. This is suggested by the strong relationship observed in this research between word recognition and reading comprehension performance as a primary source of improvement in fluency. The findings of this study are also consistent with the current researches suggesting that fluency and comprehension are linked not only because they both provide processing individual words but also because they both involve processing of syntactic units. The present study findings support the multidimensions of fluency, prosody, automaticity and accuracy.

\section{Conclusion, suggestions and recommendations:}

From the results of the present study, it can be concluded that:

The method of Readers Theatre (RT) was developed to help struggling readers; primary stage pupils and improve their fluency, accuracy and comprehension. In the classroom during training, reading aloud by the teacher, pupils or peers, is an important first step toward developing fluency, decoding and comprehension skills and necessary 
proportion for silent reading. Readers Theatre techniques presented in this study are assigned to help learners achieve reaching fluency and have as much value in the L2 classroom as in L1 classroom. As L2 Read aloud and convey the message of the text to sympathetic and interest listeners, they strengthen their skills and self-confidence. The most important Readers Theatre activities encourage L 2 learners /pupils to practise the skill more frequently which is critical to the development of advanced proficiency. It can also be concluded that the pupils improved their oral reading rates with the intervention over base line levels. Some of the pupils reached the benchmark goals novice readers at the end of the study.

The results also confirmed that the oral reading strategies used in the present study were an effective fluency building intervention for primary pupils. This is especially true in inclusive settings in which pupils are engaged in meaningful reading activities at their instruction level. At the end of the study, the pupils read with more accuracy at faster rate and hence comprehended texts. From the qualitative and quantitative analysis of the study reaults, it is clear that using Readers Theatre to develop fluency appears best suited for beginning readers who had difficulty with pacing, expression or word recognition. It has given them opportunities to read authentic texts and begin to acquire such as flow, fluidity, and comprehension. It helped them to take on and enjoy reading process.

- The more they read, the more they improve their reading abilities and reading confidence.

They have been motivated to a great degree, this is also may be due to the fact that Readers theatre supports the learning of English by creating confident reader who enjoys reading and greater self - esteem. Readers Theatre has been used consequently in every session and practised during the whole session of the program along with variety of strategies. This is because Readers Theatre supports and works as a scaffold for the beginning 
readers by providing them with short - term, achievable, mini goals such as completing a passage in faster time (speed) to increase words read correctly (accuracy), and reading for a better understanding of the text (comprehension). The resulting success of learner's experience through Readers Theatre (hold) their confidence and encouraged them to invest more time and effort into achieving the skill of reading fluency. The training program based on Readers Theatre has provided readers with significant opportunities to practise reading connected text.

\section{Suggestions for further research:}

Within the limitations of this study as well as the results being achieved, the following suggestions for further research are presented;

- Further research might examine how the multiple levels of fluency and comprehension are related when motivation is also assessed.

- Assessment of fluency is at multiple levels that may be particularly important to be studied in reading intervention.

Researches as word syntactic and passage level fluency. Fluency instruction must be complemented with additional instruction in vocabulary and comprehension which allows students to integrate the various components of reading fluency into a unified process.

- Stressing cueing system from the early stages of learning which namely includes phonological syntactic and semantic cues in an equal proportion. - Employing teaching rating from the early beginning to identify the pupils' reading proficiency as well as other measures of reading proficiency as well as assessment of phonological, morphological and grapheme or phonological awareness.

- Fluency development can be effectively scaffold through various approaches to oral reading, provided that the type of oral reading instruction is carefully matched to the need of the learner. 
- The study of the relationship between the characteristics of the reader and features of the text need to be further researched to reveal the interaction between the two recommendations. In the light of the results of the study and its discussion, the recommendations go to the teacher, pupils and curriculum designers as follows:

- The teachers as well as the curriculum designers must work together to stress oral reading fluency at the early stage of learning and the teachers are to accommodate and optimize this tendency by developing appropriate learning activities which enhance oral proficiency in reading, At the same time, the teachers and curriculum designers must focus on the points of similarities and differences between reading in the first language and reading in the second language.

- The text books must include texts which support all components of fluency development such as accuracy, prosody and automaticity as well as material for struggling readers who need support to develop fluency skills.

- The teacher must train the pupils all the time on how to self correct in order to be able to achieve their fluency.

- Providing the primary stage pupils with sufficient exposure to oral experience with reading that can be challenging task, in particular, pupils who are not yet fluent readers and seldom read when it is not required and read not to enjoy the process.

- Providing supplementary material all the time which focus on how to read orally and how to acquire the components of reading fluency as well as the way of practising them.

\section{Terminology:}

\section{Readers Theatre:}

Readers' Theatre is based on transforming a text into a script involving many characters. The script is then performed for an audience (other teachers and students) through oral reading (El- Bassuony, 2010: 64). 
Readers' theatre has been defined as a form of drama in which the actors stand or sit on stools with their scripts in hand as they read their part. The action of the drama is based solely on the voice and facial expressions of the actor instead of their movement. (Kariuki, 2012:13-14)

The researcher presents an operational definition of Readers Theatre as follows: Readers Theatre transforms the text into script through certain steps; every pupil performs his/her role in front of classmates, (or audience) expressively, through voices and actions. Pupils are the center of teaching process. It aims to develop EFL Reading Fluency skills of the pupils and enhance their motivation towards reading English language. The teacher's role is a facilitator and a guide.

\section{EFL Reading Fluency:}

EFL Reading fluency is defined as the number of correctly read words per minute when orally reading connected text. ORF is often a target area for intervention and assessment when word recognition, slow or choppy oral reading, and comprehension deficits are observed (Glazer, 2007: 4). Reading fluency refers to reading text quickly, accurately, with good prosody, and with comprehension. (Hussien, 2014: 75)

The researcher presents an operational definition of Reading Fluency as follows: The ability of pupils, to read a text, quickly, correctly, and with good prosody. It is assessed by grades which students have in reading fluency skills test and used checklist. The teacher's role is a facilitator and a guide.

\section{EFL Reading prosody:}

Reading with good expression and enthusiasm throughout the text. Varies expression and volume to match the pupil's interpretation of the passage. Generally reads with good phrasing, mostly in clause and sentence units, with adequate attention to expression. Generally reading smoothly with some breaks, but resolving word and structure difficulties quickly, usually through self-correction. Consistently reading at conversational pace; appropriate rate throughout reading. (Zutell, 1991) 


\section{References:}

Ahmed, A. A. (2016). The Effectiveness of Semantic Mapping Strategy And DR-TA Strategy In Developing Secondary School Students EFL Reading Comprehension Skills. (Doctoral dissertation), Faculty of Education, Ain shams university.

Alhaidari, M. S. (2006). The effectiveness of using cooperative learning to promote reading comprehension, vocabulary, and fluency achievement scores of male fourth- and fifth-grade students in a Saudi Arabian school. (Doctoral dissertation), The Graduate School Department of Educational Leadership, The Pennsylvania State University. Available at: http://media.proquest.com/media/pq/classic/doc/1208146221/fmt/ ai/rep/NPDF?hl=\&cit\%3Aauth

Alqayedy, A. (2014). Remediation of reading fluency and comprehension skills of early adolescent Arabic students through the use of repeated reading strategies. United States. (Unpublished master's thesis), California State University, Los Angeles. Available at: http://search.proquest.com/pqdtglobal/docview/1611854543/abstrac $\underline{\mathrm{t} \text { ? source }=\text { fedsrch\&accountid }=37552}$

Al-Sanhani, H. A. Q. (2015). Developing Pragmatic Fluency of Yemeni English Majors Through a Conversational Implicature-Oriented Program. (Doctoral dissertation), Faculty of Education, Ain Shams University.

Callard, K. (2008). Using Reader's Theater to Increase Third Graders' Reading Fluency, Comprehension, and Motivation. (Doctoral dissertation), Nova Southeastern University. Retrieved from http://accountability.leeschools.net/research_projects/pdf/Callard.pdf 
Caudill-Hansen, K. J. (2009). Readers' Theater as a Strategy to Increase Comprehension and Fluency in Sixth Grade Students. (Doctoral dissertation), College Of Education, Walden University. Retrieved from

http://media.proquest.com/media/pq/classic/doc/1920866031/fmt/ ai/rep/NPDF?hl=\&cit\%3Aauth=Caudill

Commeyras, M., Inyega, H. N. (2007/April/May/June). An integrative review of teaching reading in Kenyan primary schools. Reading Research Quarterly, International Reading Association, 42 (2), 258-281.

Diab, A. A. M. (2015). The Effectiveness of a Suggested Program Based on "Engelmann's Corrective Reading" in Developing Reading Fluency Skills among EFL Students at the Faculty of Education. (Unpublished master's thesis), Faculty of Education, Benha University.

Educational Leadership (2004). What Research Says About Reading. 61, 6: 46-51.

El-Bassuony, J. M. (2010). The Role of Readers theatre in Developing Speaking Skills and Reducing Speaking Anxiety of EFL Secondary School Students: An experimental study. Faculty of Education Journal, Port Said University, 8, 57- 107.

El-Garawany, M. S. M. (2010). The Effects of Repeated Reading Strategies on Developing Oral Reading Fluency and Reading Comprehension among EFL Prospective Teachers. (Unpublished master's thesis), Faculty of Education, Minufiya University.

El-Garhy, N. S. M. (2017/April, part 2). Enhancing Some Reading Fluency Skills of Third Year Preparatory Students through a Brain-Based Strategy. Journal of Faculty of Education, Benha University. 28 (110), 1-30. 
Farahat, A. M. M. (2014). The Effectiveness of Using Peer-Assisted Reading Strategies in Developing Sixth Graders Elementary Stage Reading Fluency and Comprehension in English as a Foreign Language. (Unpublished master's thesis), Faculty of Education, Minia University.

Fry, M. E. (2010). The Effect of Repeated Readings Within Readers Theater on the Reading Fluency Rates of At-Risk Third Grade Students. (Doctoral dissertation), College of Education, Walden University. Retrieved from http://media.proquest.com/media/pq/classic/doc/2013117391/fmt/ ai/rep/NPDF?

Glazer, A. D. (2007). The Effects of a Skill-Based Intervention Package Including Repeated Reading and Error Correction on the Oral Reading Fluency of At-Risk Readers. (Doctoral dissertation), University of Connecticut. Retrieved from http://media.proquest.com/media/pq/classic/doc/1288666701/fmt/ ai/rep/SPDF

Gummere, S. L. (2004). Readers Theater: Its impact on oral reading fluency, retell comprehension and motivation to read in first graders. (Doctoral dissertation), University of Virginia. Retrieved from

http://search.proquest.com/pqdtglobal/docview/305105083/abstrac $\mathrm{t}$ ? source=fedsrch\&accountid=37552 (UMI No. 3149155)

Hegazy, M. F. A. (2012). The effectiveness of a proposed repeated reading program in developing English language oral reading fluency and comprehension skills of preparatory school students /Thesis (Ph.D.) - Cairo University - Institute of Educational Studies.

Helwa, H. S. A. A. (2010). The effectiveness of using annotation strategy in developing some reading comprehension skills among EFL college students. (Unpublished master's thesis), Faculty of education, Benha university. 
Hussien, A. M. (2014). The Indicating Factors of Oral Reading Fluency of Monolingual and Bilingual Children in Egypt. International $\begin{array}{llll}\text { Education } & \text { Studies, } & 7, & \text { (2), }\end{array}$ http://files.eric.ed.gov/fulltext/EJ1068909.pdf

Jeon, E. H. (2012). Oral reading fluency in second language reading. Reading in a Foreign Language, 24, (2), 186-208.

Kariuki, P. N. (2012). The Effects of Readers' Theatre-Based and Tradition-Baed Instruction on Sixth-Grade Students' Comprehension at a Selected Middle School. A Paper Presented at the Annual Conference of the Mid-South Educational Research Association, Lexington Kentucky, November 7-9. Retrieved from http://files.eric.ed.gov/fulltext/ED537896.pdf

Marc, S. \& Ronald, G. (1994). PROSODY AS A MARKER OF INFORMATION FLOW IN SPOKEN DISCOURSE. Language \& Speech, 37(1), 21-43.

Morales, B. (2013). The effects Reader's Theater has on 3rd and 4th grade English language learners literacy skills and self-esteem in the ESL classroom. (Master's thesis), The William Paterson, University Of New Jersey. Retrieved from http://gradworks.umi.com/15/48/1548575.html

Moran, K. J. K. (April/2006). Nurturing Emergent Readers Through Readers Theater. Early Childhood Education Journal, 33 (5), 317 323. DOI: $\quad 10.1007 / \mathrm{s} 10643-006-0089-8$ http://000wmlh.1104.y.https.link.springer.com.mplb1ci.ekb.eg/co ntent/pdf/10.1007\%2Fs10643-006-0089-8.pdf

Mraz, M., Nichols, W., Caldwell, S., Beisley, R., Sargent, S., and Rupley, W. (2013, January/February). Improving Oral Reading Fluency through Readers Theatre. Reading Horizons, 52 (2), 1-3. https://www.questia.com/library/journal/1P32948869801/improving-oral-reading-fluency-through-readers-theatre 
Priestle, M. (2009). Standardized Test Practice: Long Reading Passages (Grades 3-4). Scholastic Inc. New York, the U.S.A

Ramadan, H. F. M. (2016). A Suggested Integrative Reading Strategy to Develop EFL Prep School Students' Oral Reading Fluency and Vocabulary Acquisition. M A Thesis, Faculty of Education, Zagazig University.

Rasinski, T. V. (2004). Assessing Reading Fluency. Pacific Resources for Education and Learning. Retrieved from http://files.eric.ed.gov/fulltext/ED483166.pdf http://www.lewistonschools.net/departments/curriculum/ELA/Ass essing luency.Rasinksi.pdf

Sailer, J. K. (2006). The Effects of Reader's Theater on 6th Grade Students Fluency, Comprehension, and Reading Attitude. (Master's thesis), The College of Education and The faculty of the Graduate School of Wichita State University. Retrieved from http://media.proquest.com/media/pq/classic/doc/1225138611/fmt/ ai/rep/NPDF?hl=\&c

Selim, A. S. M. (2004). Measuring the readability of the reading texts of the English book "Hello! 5" for the third year prep pupils. (Unpublished master's thesis), Institute of Educational Studies, Cairo University.

Sullivan, L. E. (2009). The SAGE Glossary of the Social and Behavioral Sciences. Publishing Company: SAGE Publications, Inc. http://08114jf2b.1106.y.http.sk.sagepub.com.mplbci.ekb.eg/refere nce/download/behavioralsciences/n980.pdf

Trainin, G. and Andrzejczak, N. (2006). Readers' Theatre: A Viable Reading Strategy? University of Nebraska at Lincoln Education and Human Sciences, College of (CEHS) Great Plains Institute of Reading and Writing, A paper presented at the American Educational Research Association meeting. Retrieved from https://www.researchgate.net/publication/264878150_Readers'_Th eatre_A_Viable_Reading_Strategy 
Tsou, W. (2011, Winter). The Application of Readers Theater to FLES (Foreign Language in the Elementary Schools) Reading and Writing. Foreign Language Annals, National Cheng Kung University, 44, (4), 727- 748. Retrieved from http://www.laits.utexas.edu/introgerman/sites/laits.utexas.edu.intro german/files/Article\%202.pdf

Vygotsky L. S. (1930). Mind and Society. Harvard University Press.

Retrieved from

http://www.cles.mlc.edu.tw/ cerntcu/099curriculum/Edu_Psy/EP 03_New.pdf

Vygotsky, L. S. (1978). Mind in Society: The Development of Higher Psychological Processes. Harvard University Press. Cambridge, London. Retrieved from http://ouleft.org/wpcontent/uploads/Vygotsky-Mind-in-Society.pdf

Za'za', M. S. M. (2014, October). The effect of teacher- and peermediated repeated reading on the oral reading fluency and reading comprehension among sixth- grade primary stage pupils. Journal of Faculty of Education, Benha University, 100 (1), 1-46.

Zutell, J., \& Rasinski, T. V. (1991). Training teachers to attend to their students' oral reading fluency. Theory Into Practice, 30, 211-217. 